\author{
A.A. Imanbayeva* \\ Mangyshlak experimental botanical garden, Aktau, Kazakhstan \\ (*E-mail: imangarden@mail.ru)
}

\title{
Assessment of the perspectivity of introduction of woody plants in the arid conditions of Mangystau
}

\begin{abstract}
The introductory study and identification of promising and sustainable taxa of woody plants is important for green construction and ornamental gardening of Kazakhstan. It is important to choose sustainable crops for arid conditions characterized by extreme conditions and deficient woody plants of local flora. This article presents data on the study of the rhythms of seasonal growth and plant development. There are differences that are expressed in changing the timing of the onset of vegetation (5-10 days), flowering and fruiting (1520 days) and reducing their duration. In the arid conditions of Mangyshlak, according to the vegetation dates, there was an increase in plant prospects for phenogroups from PP (previously the beginning and earlier the end of vegetation) to PП (previously the beginning and later the end of vegetation), a decline in CP (the middle beginning and earlier the end of vegetation) and an increase in CC (the middle beginning and the middle end of vegetation). From the 183 introduced plants 52 taxa belong to the first perspective group (high), 95 taxa - to the second group (elevated), 34 taxa - to the third (medium) and 2 taxa - to the fourth (low) of the selected 6 pheno groups. These data indicate the success of the introduction and the prospects for their further use. An electronic database on collectible woody plants is being formed on the computer program «DInCeR,» developed by the Mangyshlak Experimental Botanical Garden.
\end{abstract}

Keywords: Mangystau, arid conditions, introduction, woody plants, phenology, growth and development, perspectivity.

\section{Introduction}

The success of the introduction process depends on the correct combination of the biological characteristics of woody plants with the ecological, climatic conditions of the introduction area. In the arid conditions of Mangystau, the introduction of plants depends on a whole complex of factors: winter resistance, drought resistance, heat resistance, salt resistance, etc. [1].

The main limiting factor is the strong continental climate. According to long-term data on the climatic characteristics of Mangystau, winter is short-term, characterized by unstable snow cover and frequent thaws, but rarely cold winters. Unstable snow cover in cold winters leads to deep freezing of the soil. The average temperature of the coldest month January varies from -3 to $-10{ }^{\circ} \mathrm{C}$. In some years, sharp deviations from the norm are observed. There were cases when in January the temperature dicreased until $-26 \ldots-31^{\circ} \mathrm{C}$. Winter Period on Mangyshlak is the windiest period. Often, the absolute wind speed exceeds $15-20 \mathrm{~m} / \mathrm{s}$.

The very severe conditions are carried out by introduced plants in the summer. The summer months are dry and stably hot with the large amplitude of fluctuation in daily temperatures. Absolute maximum is $+40-45^{\circ} \mathrm{C}$, when heating the soil to $+60-70{ }^{\circ} \mathrm{C}$. Days without sun are practically absent. The evaporability of moisture exceeds the amount of precipitation by 10-15 times, dry winds are not uncommon, with a wind speed of $15-16 \mathrm{~m} / \mathrm{s}$. The average annual air temperature is $+9.6-11.5^{\circ} \mathrm{C}$, the absolute minimum is $+34{ }^{\circ} \mathrm{C}$, maximum is until $+47^{\circ} \mathrm{C}$. Annual falls are $107-181 \mathrm{~mm}$. There are frequent strong winds, which lead to the spread of dry winds, dust storms, and the removal of salts from the Caspian.

The soils of the territory are zonal brown, from weakly alkaline to neutral, characterized by chloridesulfate salinization and underdeveloped profile. At a depth of up to 7-8 $\mathrm{m}$, there is bedrock in the form of Sarmatian limestone, which serves as a water stop and has large cup-shaped closed depressions filled with loose rocks - a gravel mixture and a shell. Soils are poor in humus, nitrogen and phosphorus.

This brief information on some indicators of the natural conditions of Mangystau gives an idea of the main tasks facing scientific botanists, for the correct organization of the introductory process. Woody plants should have hereditary deep winter rest, have reliable cover tissues that protect them from winter drying and summer burns. They should finish growing early and retire with well-matured wood. Plants need to have high physiological frost resistance, since the absence of snow cover leads to freezing of root systems [2]. No less stringent plant conditions are encountered during the growing season. High summer temperatures and 
wind conditions require intensive watering. Planting is carried out in specially prepared dug pits, beds and checks with application of soil 40-50 t/ha of organic fertilizers and sawdust.

The aim of the study is to study the features of growth and development to identify the most promising woody plants in the area of introduction in the arid conditions of Mangystau.

\section{Methodology}

Objects of investigation were 169 species of deciduous woody plants belonging to 61 gena: Acer -6 , Ailanthus - 1, Amygdalus - 1, Amorpha - 2, Armeniaca - 1, Amelanchier - 1, Berberis - 14, Celtis - 1, Catalpa - 2, Caragana - 3, Cerasus - 2, Cersis - 1, Cladrastis - 1, Cotoneaster - 8, Cornus - 3, Colutea - 1, Crataegus - 14, Cydonia - 1, Elaeagnus - 2, Euonymus - 4, Lonicera - 8, Ligustrum - 2, Juglans - 2, Forestiera - 1, Forsythia - 1, Fontanesia - 1, Fraxinus - 4, Gleditsia - 3, Gymnocladus - 1, Koelreuteria - 1, Haloxylon - 2, Halimodendron - 1, Hemiptella - 1, Maclura - 2, Malus - 10, Mahonia - 2, Morus - 1, Mespilus - 1, Nitraria - 1, Pallurus - 1, Padus - 5, Platanus - 1, Populus - 3, Ptelea - 1, Physocarpus - 2, Philadelphus - 2, Pyrus - 5, Prunus - 1, Salix - 3, Sambucus - 1, Sorbus - 1, Quercus - 2, Rhamnus - 4, Rosa- 6, Robinia - 1, Rhus - 3, Tilia - 2, Sophora - 1. Spiraea - 1, Symphoricarpos - 4, Viburnum - 3, Zanthoxylum - 1, Ulmus - 1, attracted for introduction in period 1990-2000. Long-term observation makes it possible to identify the most promising species in the introduction of arid conditions of Mangistau.

To compare and assess the prospects for the ranges, 65 species of North American, 56 species of the Central Asian, 62 species of the Eastern Asian floristic regions, mainly reaching the age of flowering and fruiting, were subjected.

The study of the rhythms of seasonal plant development and the prospects of introduced plants was carried out according to the phenological observation technique developed for botanical gardens [3]. Assessment of drought resistance was carried out on the scale of S.C. Pyatnitsky [4]. Winter resistance was determined visually on a 7-point scale [5]. Most attention was paid to the study of the phases of flowering and fruiting, as the main factor of decorativeness. The height and growth of plants were also taken into account.

To assess viability and perspective, the scale compiled by P.I. Lapin and S.V. Sidneva [5], supplemented by M.N. Kosaev [6], was applied. This scale includes 7 main indicators, which are determined by systematic visual observations of general and seasonal plant development. The following features were taken into account: the degree of annual ripening of shoots, winter resistance, drought resistance, preservation of habitus, self-educational ability, regular growth of shoots, ability for generative development and available methods of propagation of tested plants in the area of introduction $[5,6]$.

Based on the analysis of the indicators and the sum of the points, the studied plants were divided into the following perspective groups: 1) Quite promising plants (the sum of points 106-115), although they are not in their ecological optimum, usually reach their characteristic size, flower and bear fruit normally, form high-quality seeds, winter stamens, drought-resistant only in unfavorable years they can have freezing annual shoots or short-term loss of turgor leaves. 2) Perspective group (sum of points 91-105). It includes plants that mostly do not reach their inherent size, bear fruit and form germinating seeds. Usually they freeze slightly, in drought the leaves can lose turgor, which is restored during watering. 3) Less promising plants (the sum of points 76-90) are characterized by slow growth, poor fruiting; often with low seed viability, mostly systematically suffer from frost or drought. 4) Low-potential plants (the sum of points 56-75) are characterized by depressed growth, do not bear fruit or bear fruit only in favorable years, as a rule, significant winter injuries or mass burns of leaves and drying of shoots in dry periods are observed.

\section{Results and discussion}

Analysis of results of adaptation capabilities of woody plants is used for objective introductive prediction and theoretical developments related to adaptation of plants in new conditions and subsequent selection of promising assortment of woody plants [7].

According to the results of many years of introduction experience, on Mangyshlak, the natural range of introduced species mainly falls on North America (65 species from 17 families and 29 genera), Central Asia (56 species from 17 families and 29 genera) and Eastern Asia (62 species from 15 families and 24 genera).

Theoretically and on the nase of the experience of plant introduction on Mangyshlak, the prospect of attracted species from North America, Central and Southern Asia that showed the best adaptation capabilities was justified, having successfully passed the introduction. 
The flora of the Atlantic North American region is rich in species promising for introduction to Europe and Asia, as confirmed by the experience of the introducers [8]. Botanists have long drawn attention to the amazing similarity of the flora of Atlantic North America with that of East Asia. This similarity of flora and their connections are expressed in the presence of a large number of common genera and close species. From the flora of Atlantic North America (Appalachian province), representatives of the genera Mahonia L., Maclura Nutt., Celtis L. have been successfully introduced on Mangyshlak. Species such as Robinia pseudoacacia, Gleditsia tricanthos, Maclura aurantacia from the North American provinces on Mangyshlak, species of the genus Amorpha L. were successfully introduced.

The flora of the Central Asia developed as xerophilic [9]. However, at the end of the Pliocene and in the Quaternary, as a result of mountain formation and glaciation, conditions were created for the penetration of mesophilic-type woody plants from Siberia, the Caucasus, northern Iran and the Himalayas. These sources served as the basis for the formation of the flora of the Small and Central Asia. Therefore, the flora includes autochthonous and alien species [10]. Under the influence of arid conditions in the Central Asia, mesophilic plants were transformed into xeromesophytes.

The Eastern Asian flora was formed at fairly high temperatures, with strong daily and seasonal fluctuations, a very low and high degree of humidification, and moderate vegetation duration. Here the center of development of cultivated plants is formed. Many researchers consider the Eastern Asia to be the center of ancient agriculture for cultivated plants, including the primary center for the formation of forms of fruit crops of Rosaceae family, gena Malus, Pyrus and Prunus, which go far beyond the centers of origin [11-13]. It was established that the conditions, in which the evolution of plants, took place impose requirements for the conditions for its growth. This is the length of the day, temperature, vegetation duration and humidity. The approach to the introduction of plants in desert areas depends on a set of agricultural measures that allow creating the closest possible conditions of the place of introduction to the conditions of the homeland of the plant (humidification, changing the physical and chemical composition of soils, etc.). When introducing plants outside their natural range, the study of their rhythms of seasonal growth and development is of great importance $[14,15]$.

From 183 taxa introduced under Mangyshlak conditions, 173 taxa (94.2\%) entered the generative phase. Among the life forms there are: 90 species of trees, 93 species of shrubs, among them the NorthAmerican - 37 trees and 28 shrubs; the Central Asian - 20 trees and 36 shrubs; the Eastern Asian - 33 trees and 29 shrubs.

Based on the results of phenological observations, it was established (Tab. 1), that swelling and unfolding of buds in early-vegetating Central Asian species (Populus alba, P.bolleana, Salix alba) and Eastern Asian species (Lonicera maackii, L. edulis, L.ruprechtiana, Padus davurica, Ligustrum tshonoskii, L. japonicum) noted in the II-III decades of February, and for many species — in the I-II-III decades of March, except for the Northern American taxa Zhanthoxylum simulans, Mahonia aguifolium, Cladrastis lutea, Juglans cinerea, J.nigra, Ptelea serrate, Philadelphus hirsutus, Ph.lewisii, Fraxinus lanceolata, Amorpha fruticosa, A.schafranifolia, Crataegus rus-galli, Cr. kellermanii, Cr. lanuginosae, Gleditsia aguatica, G. triacanthos, Robinia pseudoacacia, Gymnocladus dioecus, Cercis canadensis, Celtis occidentalis, Forestiera neo-mexicana, Platanus occidentalis, 3 species of Crataegus, 2 species of Catalpa, Gleditsia and Maclura.

The the latest beginning of vegetation was noted in the first decade of April for Asian species from the genus Pyrus, Crataegus, Fraxinus. Species from the genera Lonicera L., Fraxinus L., Acer L. bloom very early. All species of Lonicera L., Crataegus L., Berberis L., Cotoneaster Medik., Cotinus Scop., Caragana L. are flowering abundantly.

Early ripening of fruits and abundant fruiting are noted all introduced plants from genus Lonicera. Late bloom is noted for Koelreuteria apiculate, Koelreuteria bipinnata and species of genus Catalpa Scop.; the latest ripening of fruits is observed for Mespilus germanica, Zhanthoxylum simulans. With the onset of summer heat (end of June - beginning of July), leaves in Acer species (Acer sachharum, Acer negundo) and all species of Catalpa are burned; leaves of Corylus avellana are also suffer from dry air.

But, with the advent of more favorable conditions (a decline in high temperature), almost all species have young leaves, and some introducents have a secondary growth of shoots (Quercus robur, Sambucus canadensis, Caraganda arborescens). From mid-April, the growth of shoots of all collectible species begins, intensive growth has been observed since the third decade of April, and at the end of May - in early June, the growth of shoots in some species stops (representatives of families: Rosaceae and Fagaceae) [16]. 


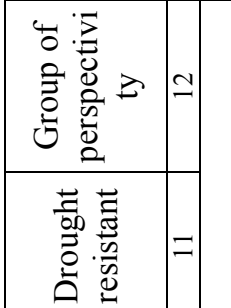

$\because \because$ 일

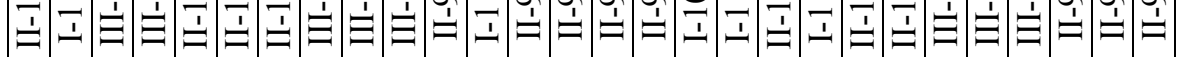

离苛苟

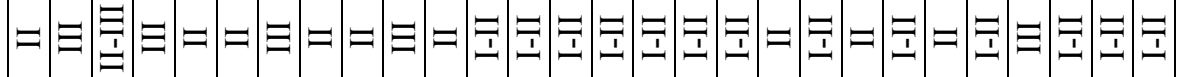

3

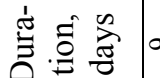

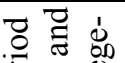

Do

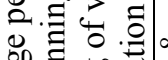

品. 者

要远

$<4$

兽离

คे

4

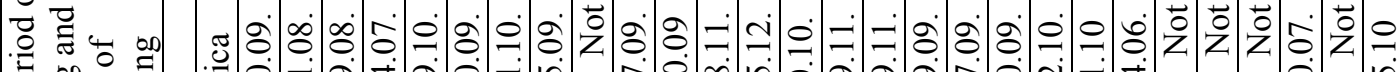

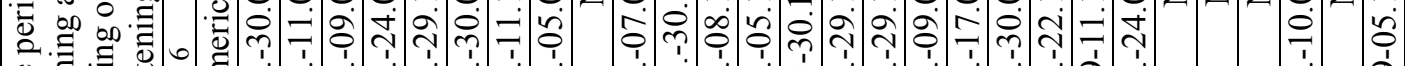

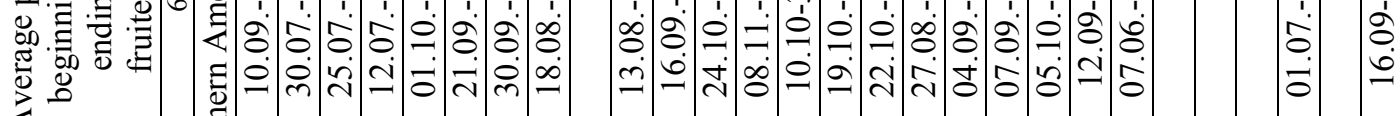

安

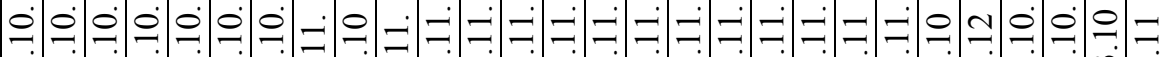
กิ กิ சं

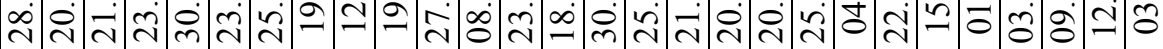

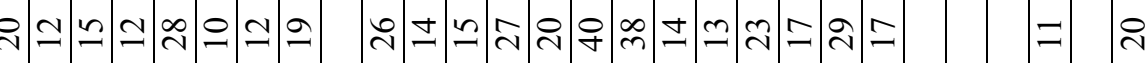

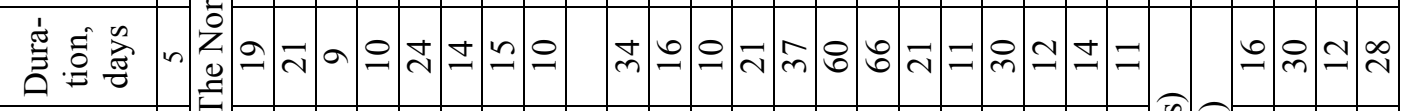
$\because \vec{\square}$

娄

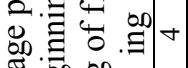

क्ष.

¿

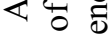

出 घ

苛 专

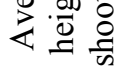

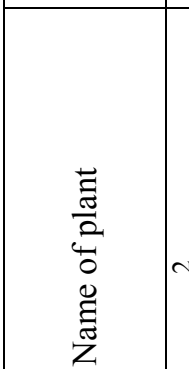

j) $\left.\begin{array}{l}-1 \\ -1\end{array}\right)$

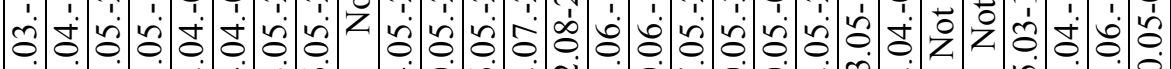
m

ते

ลิڤ

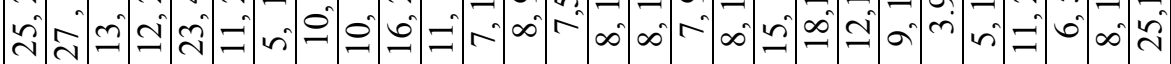

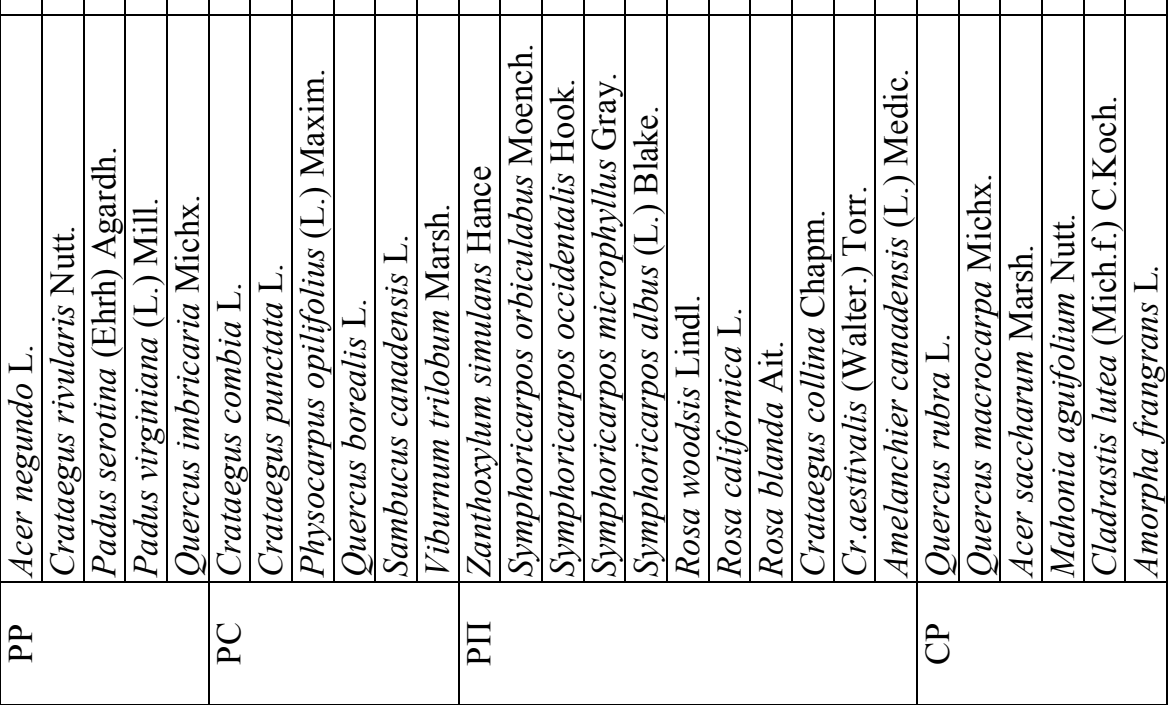




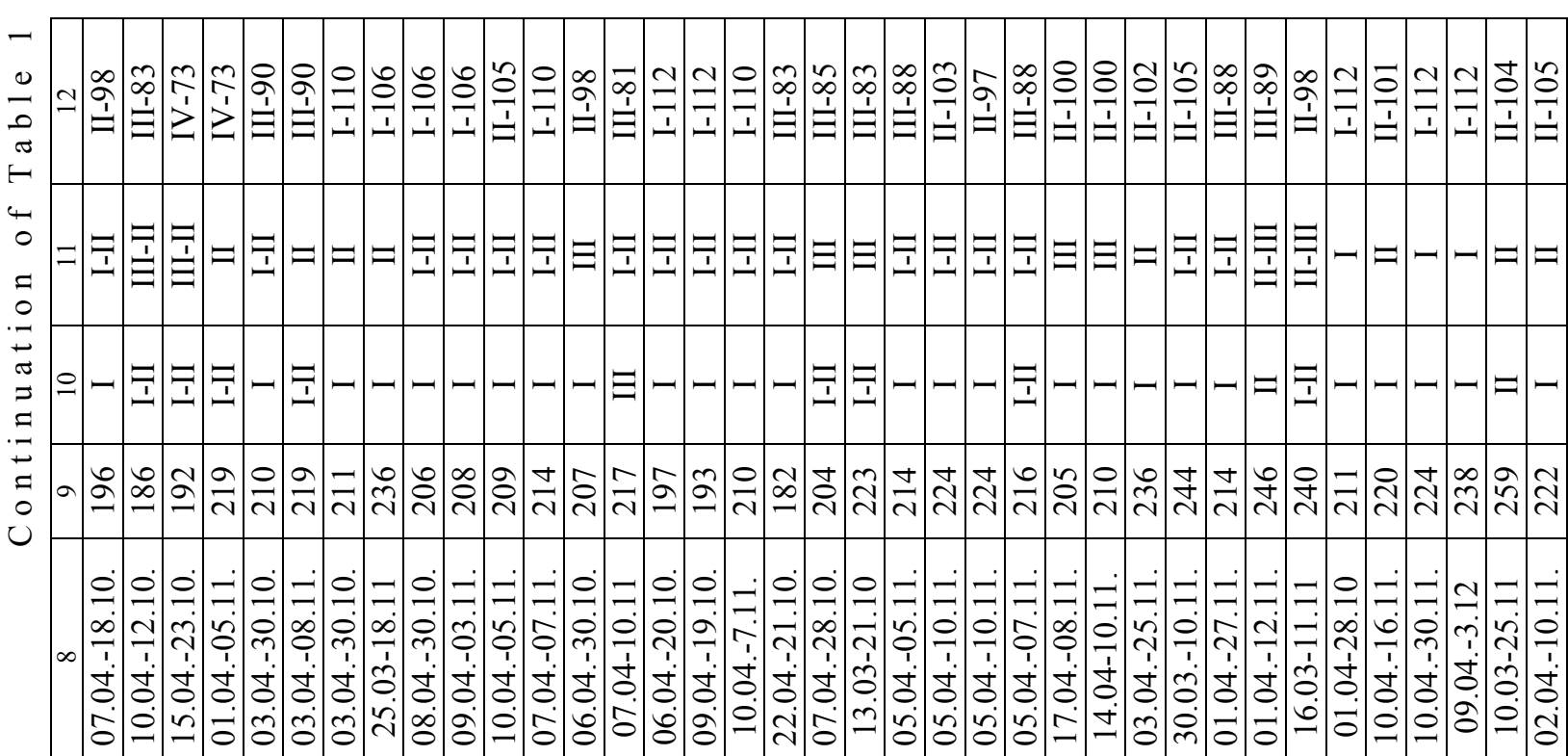

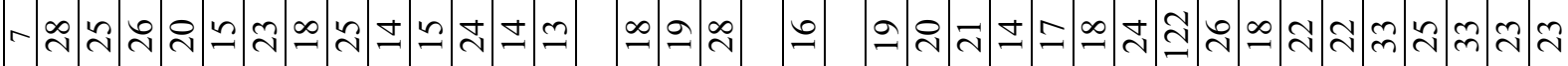

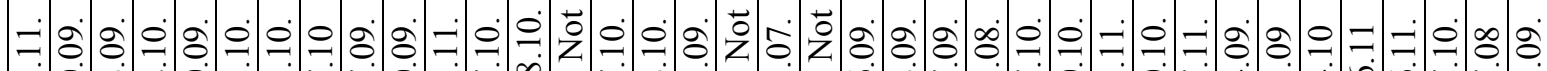

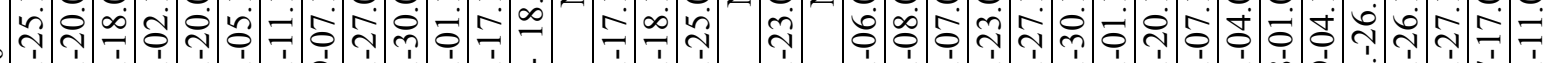

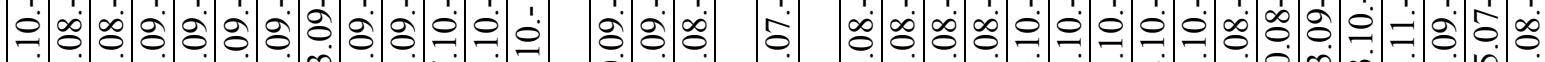

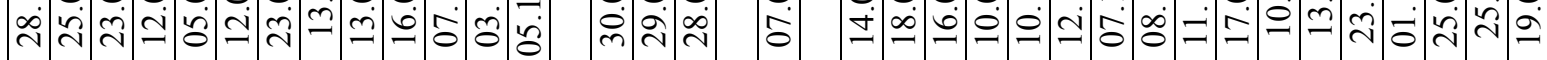

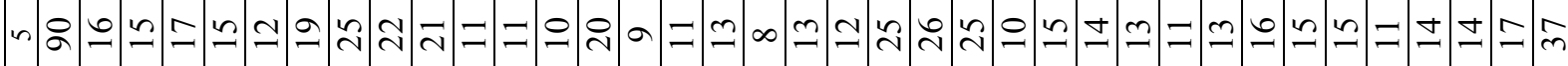

ஓं

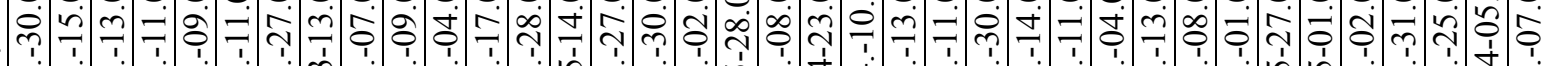
○े

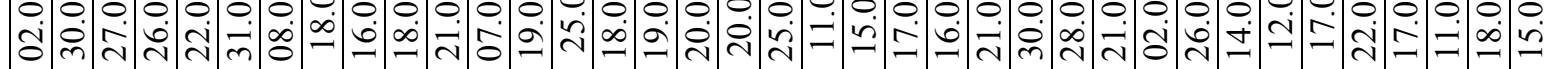

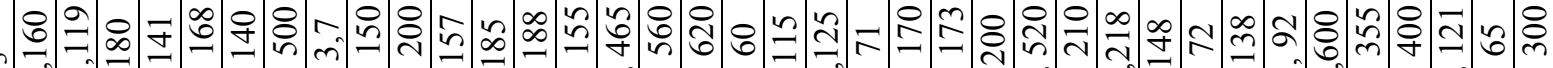

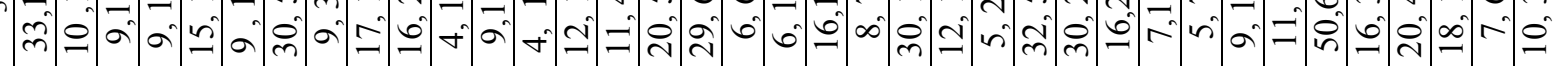

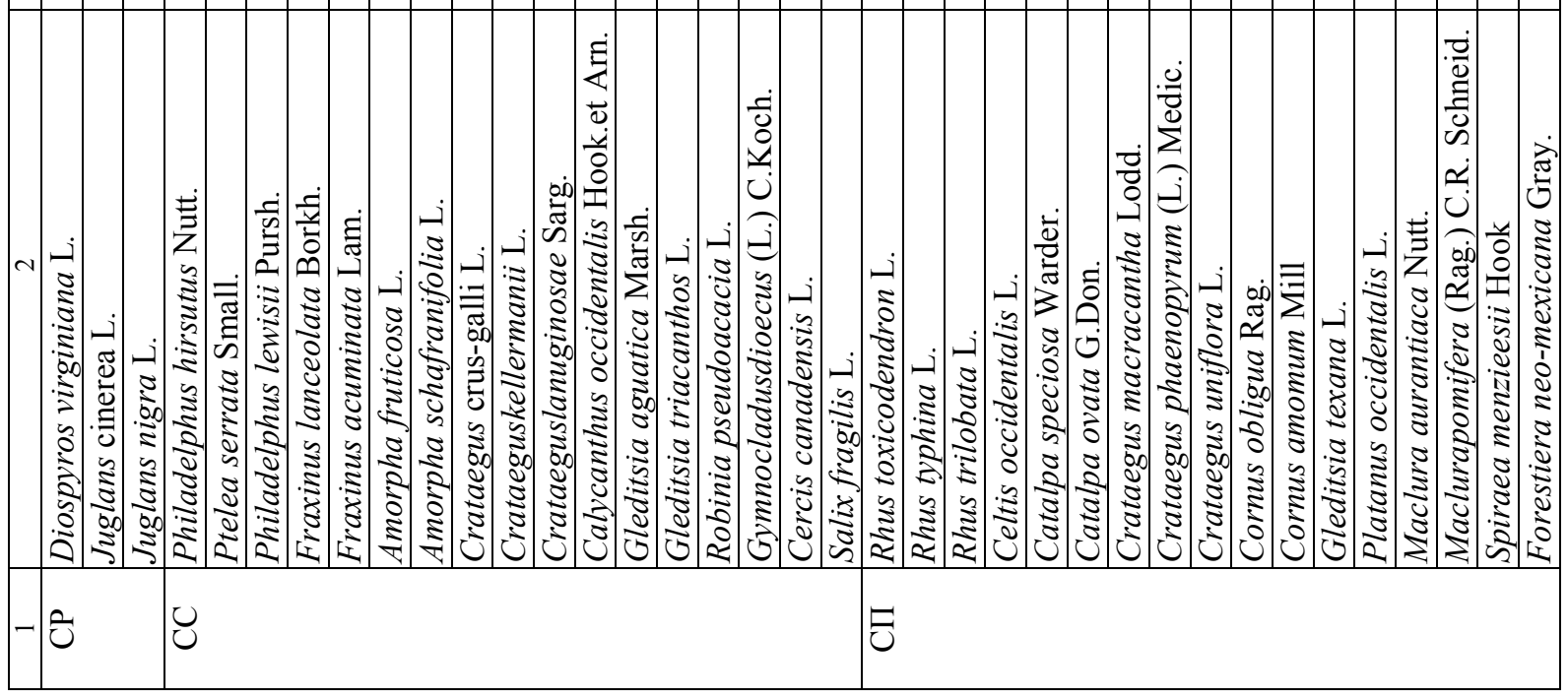




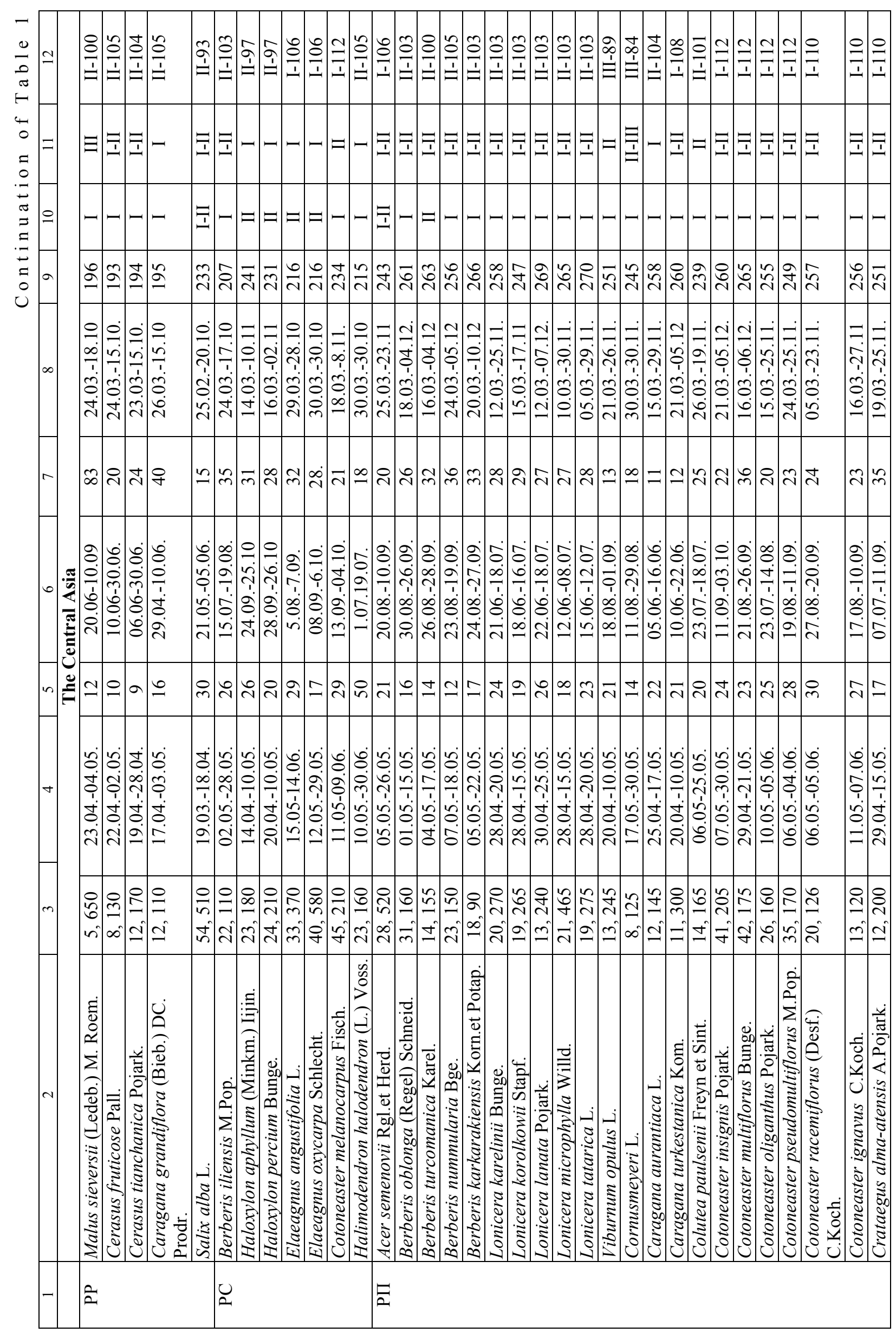




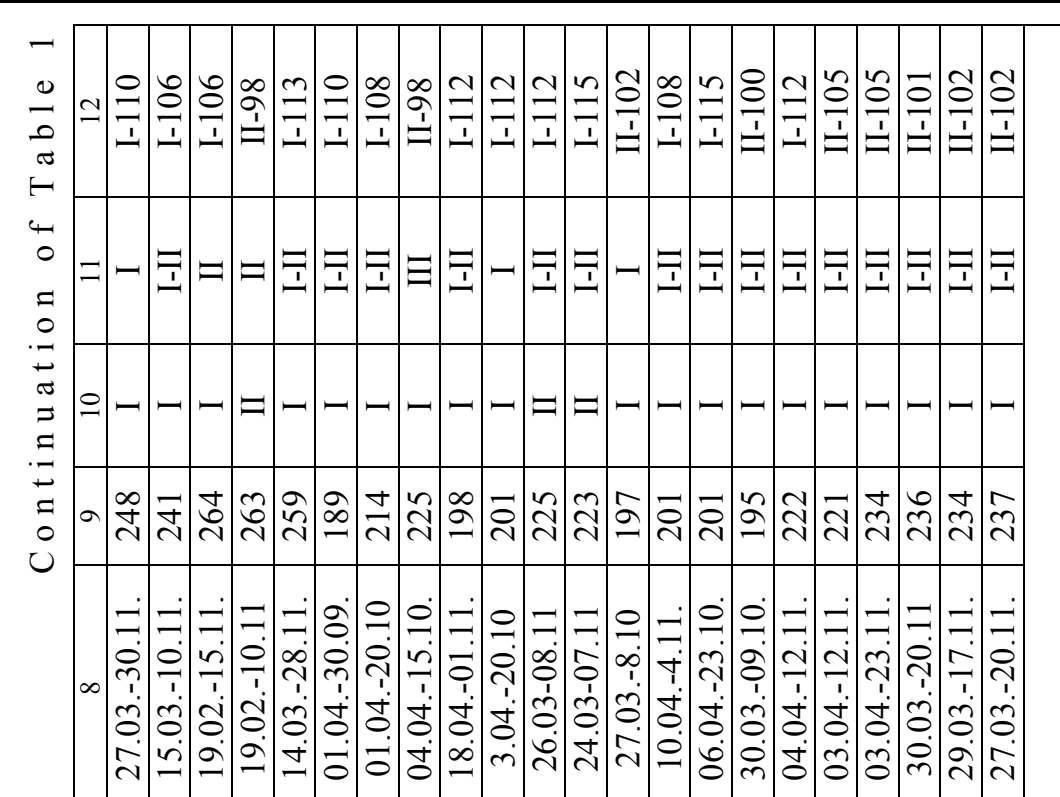

$\sim$ ง m $m$ m

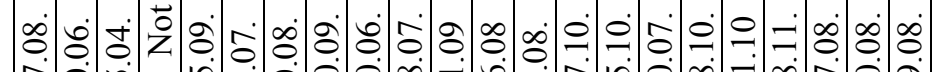

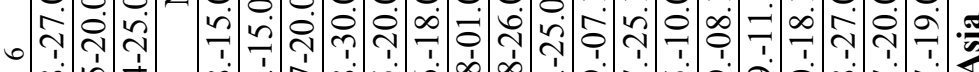

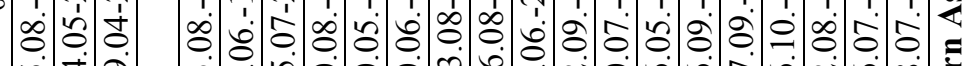

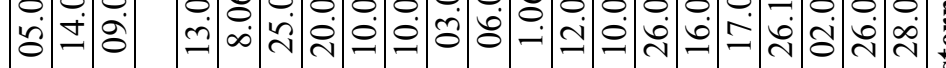

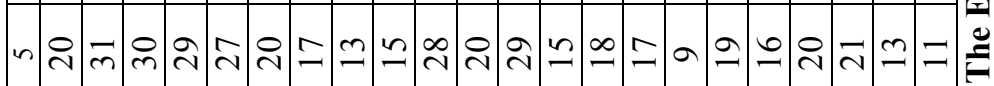

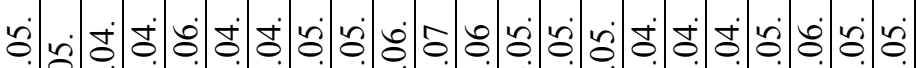

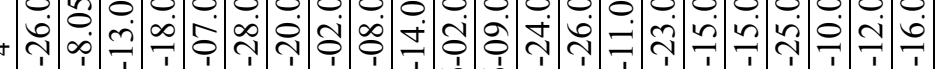
ڤ்

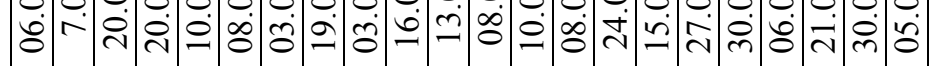

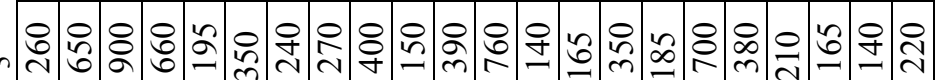

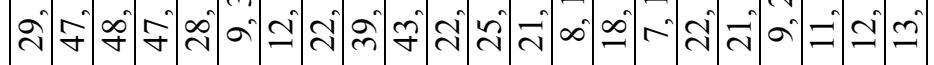

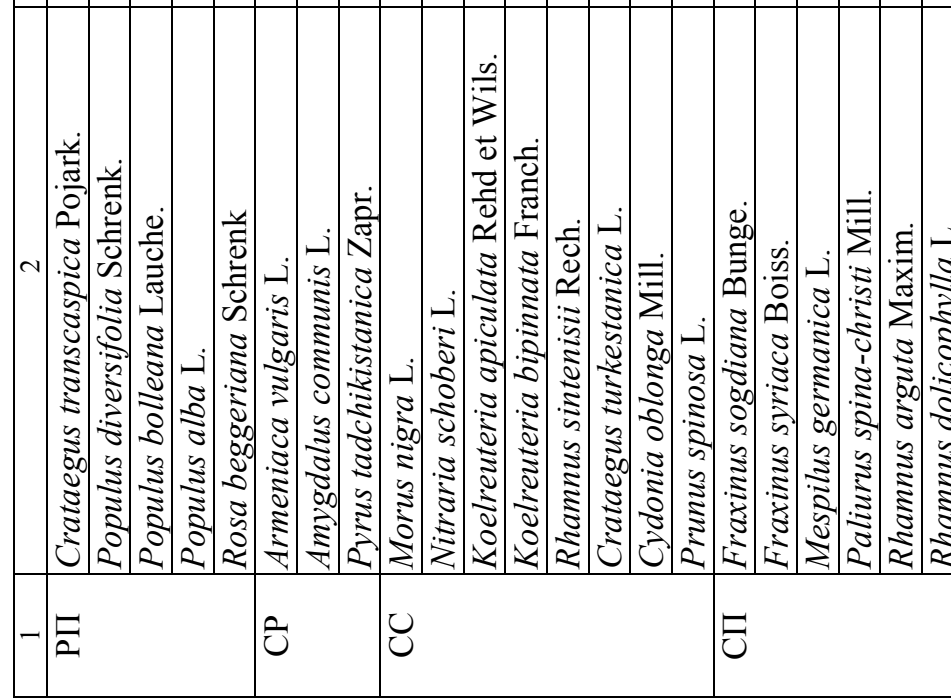

กิษ 当音音音音主主

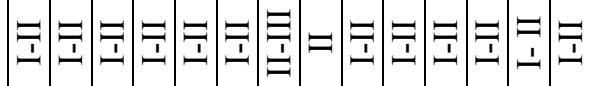

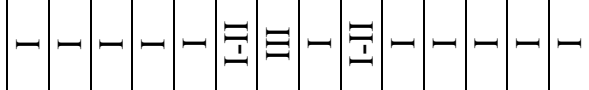

సิ సิ సิন

00000000000000

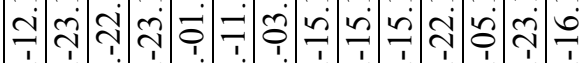

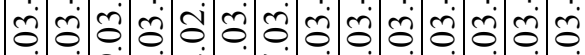
-

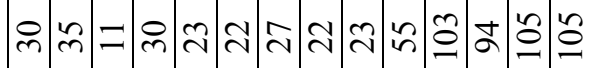

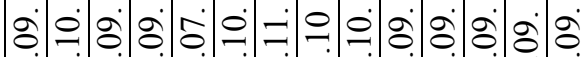

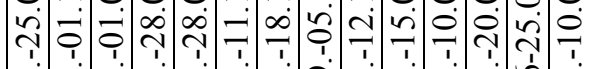

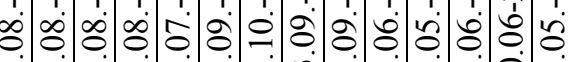
iे

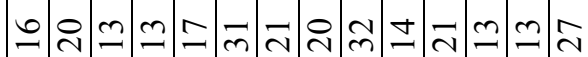

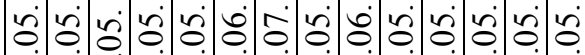

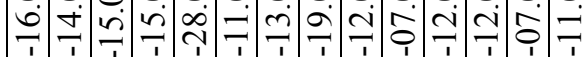

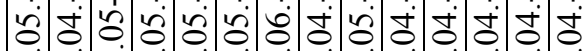
-

을을

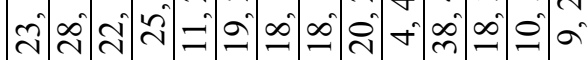

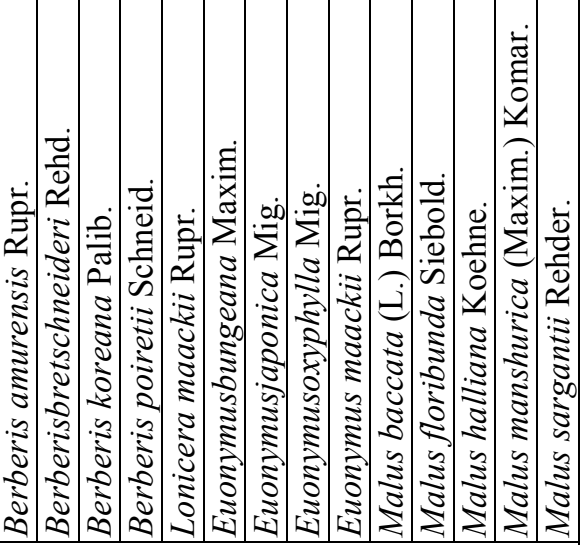

ฉิ 


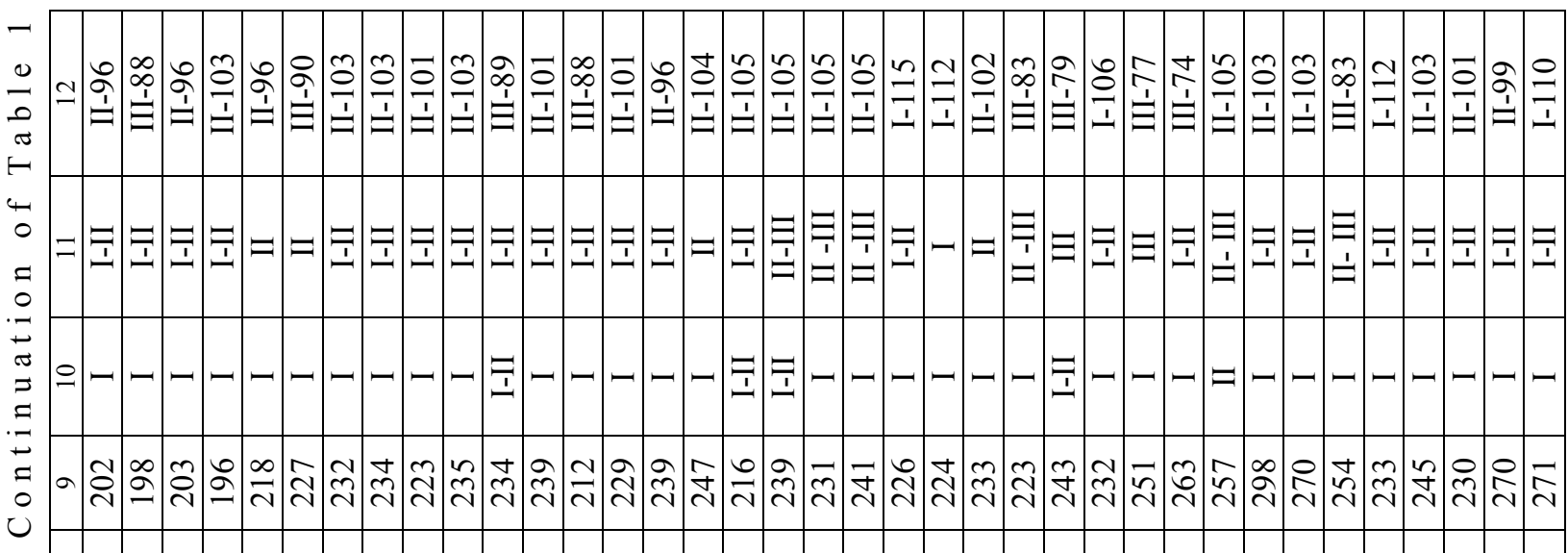

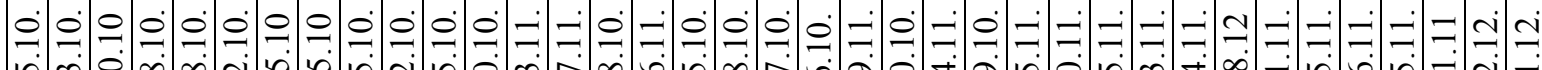

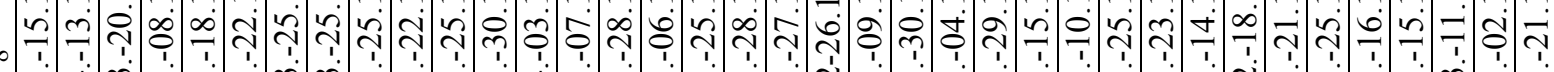

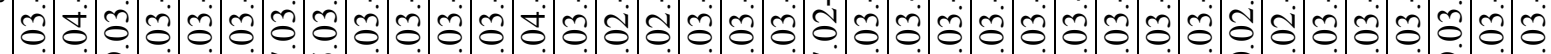

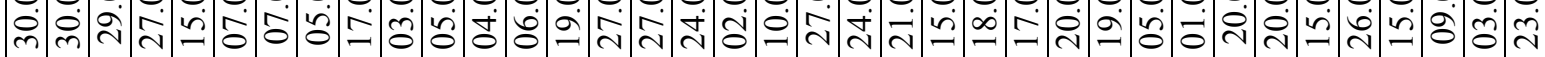

म

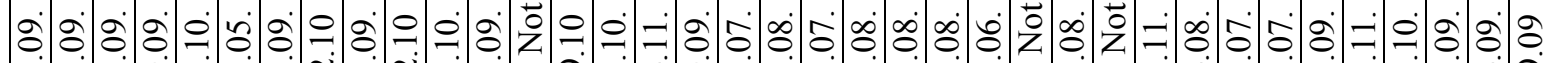

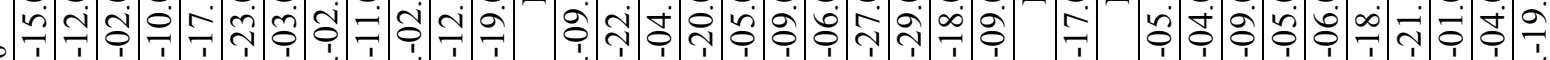

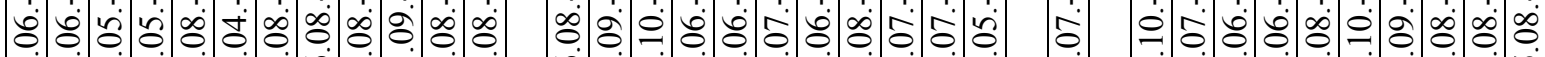

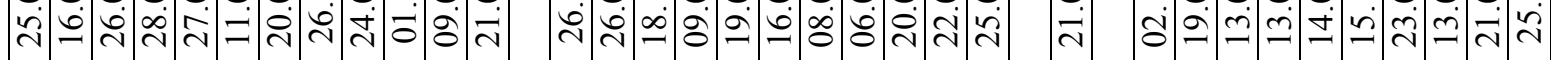

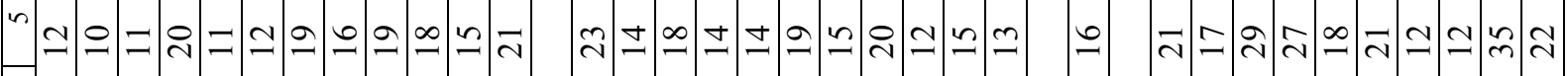

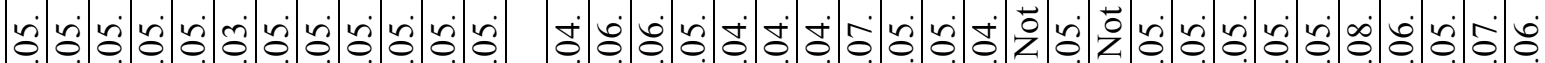

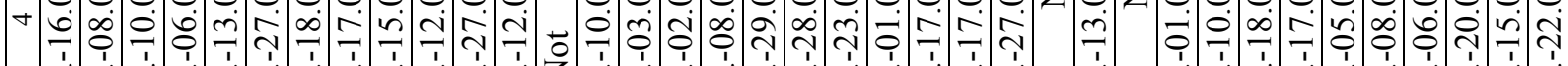

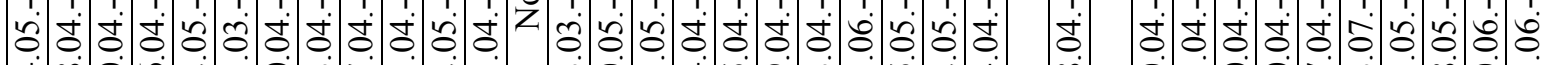
d

\& 00 ஸी

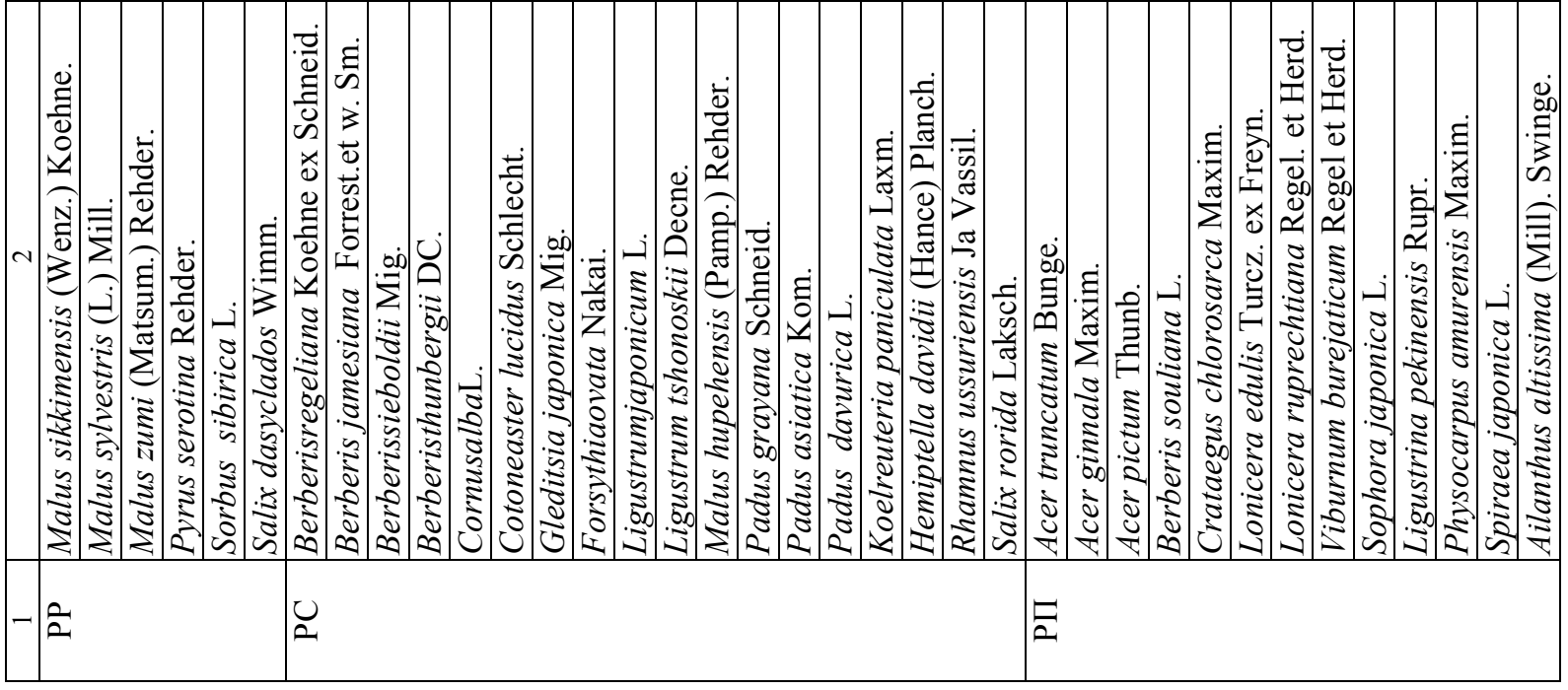




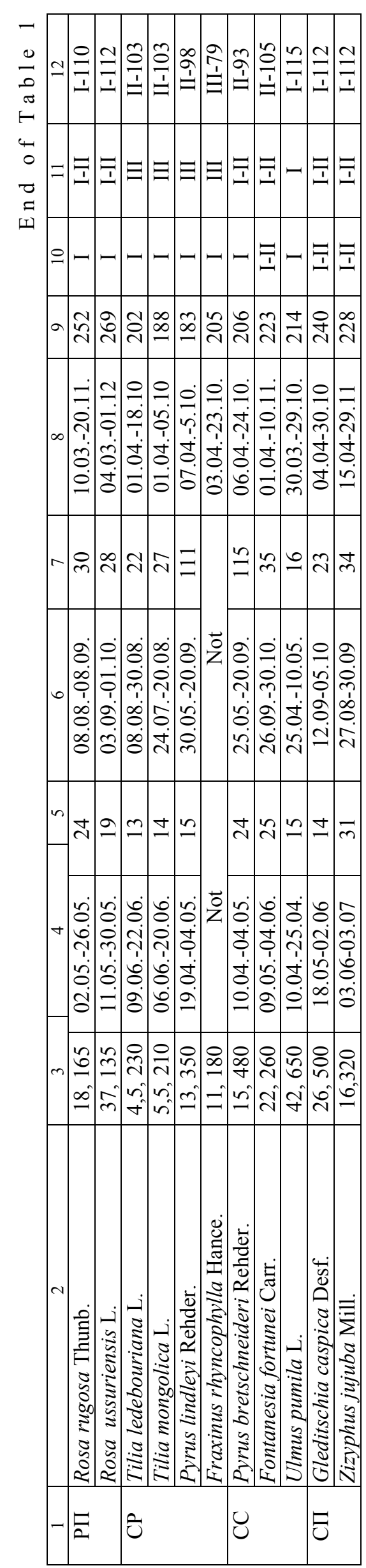


During observations of plant growth and development in the conditions of the Mangyshlak Experimental Botanical Garden, it was established that the beginning of plant vegetation depends on weather conditions. The considered introducents of deciduous dendroflore are conditionally divided into pheno groups by the dates of onset and termination of vegetation. The studied introducents according to the development dates from the beginning of swelling to the onset of mass leaf fall according to the method of S.N. Makarov [16], with some changes in local natural conditions introduced into the culture, were divided into 6 pheno groups. Under the conditions of Mangyshlak, introducents quite early begin vegetation. Those who began growing from the end of February to March 30 are classified as early; from April as secondary; from May as late. Accordingly, introducents, whose end of vegetation is noted until October, 20, are considered as early; from October, 25 to November, 10 - as average; after November, 10 - as late.

Phenogroup PP has 5 species of the North American (Acer negundo, Crataegus rivularis, Padus serotina, Padus virginiana, Quercus imbricaria) and the Central Asian (Malus sieversii, Cerasus fruticosa, C.tianschanica, Caragana fritucosa, Salix alba) - $2.73 \%$; from the Eastern Asia - 20 species (species from genera Berberis, Malus, Euonymus, also Lonicera maackii, Pyrus serotina, Sorbus sibirica, Salix dasyclados $)-10.9 \%$ of total number of the studied introduced species. The age of plants is 15-26 years, which is quite enough to determine the success of plants in introduction. All of them are characterized by the rapid end of the growth of shoots and their complete dressing. The average vegetation duration is 185-231 days. All species are winter-resistant; belong to the first and second groups of perspectives. Some species from the genera Padus, Malus and Salix dasyclados, due to poor drought resistance, belong to the third perspective groups. Introduced plants this group annually give a good increase in shoots $-12-45 \mathrm{~cm}$; fullfledged seed products. In culture, it is very well propagated by seeds of local reproduction Acer negundo, which is successfully used in green building.

Fenogroup PC has 31 species, from them the North American 6 species (Crataegus combia, Crataegus punctata, Physocarpus opilifolius, Sambucus canadensis, Viburnum trilobum, Quercus borealis), the Central Asian 7 species (Berberis iliensis, Cotoneaster melanocarpus, Halimodendron halodendron, by 2 species from genera Haloxylon and Elaeagnus); the Eastern Asian 18 species (Cornus alba, Cotoneaster lucidus, Gleditsia japonica, Forsythia ovata, Malus hupehensis, Koelreuteria paniculata, Hemiptella davidii, Rhamnus ussuriensis, Salix rorida, 3 species from genus Berberis and Padus, 2 species of genus Ligustrum) - $16 \%$ from common species composition. Plants are characterized by a timely end to the growth of shoots, giving an annual average shooting ability of 5-45 cm, an increase in the main shoots and complete lignification. All species are characterized by the beginning of vegetation on an equal footing with the first group, but the end is slightly later. Plants bloom stably and bear fruit, except for the Eastern Asian species Gleditsia japonica. The average duration of flowering and fruiting for the most introducents is $10-35$ days; the vegetation duration is 216-247 days. The most species of this group (70 \%) do not freeze, only for the Northern American, as Sambucus canadensis, Physocarpus opilifolius in the cold winter years there is a freezing of $50 \%$ of the shoots of annual growth. In summertime from this group at the Northern American species (Crataegus punctata, Physocarpus opilifolius, Sambucus Canadensis and Viburnum trilobatum) and the Eastern Asian one species (Cornus alba) partially burn leaves and some loss of turgor of leaves is observed.

According to the perspectivity, plants from this group are assigned to 2 and 3 prospect groups, except for the North American species Crataegus combia, the Central Asian species Elaeagnus angustifolia, Elaeagnus oxycarpa, Cotoneaster melanocarpus and the Eastern Asian species Koelreuteria paniculata, which belong to the $1^{\text {st }}$ group.

Phenogroup РП has 53 species, among them 11 taxa are the Northern American (Zanthoxylum simulans, Symphoricarpos orbiculabus, S. occidentalis, S.microphyllus, S. albus, Rosa woodsis, $R$. californica, R. blanda, Crataegus collina, Cr.aestivalis, Amelanchier canadensis); the Central Asian are 27 taxa (Acer semenovii, Cornus meyeri, Colutea paulsenii, 2 species of genus Caragana, 4 species of genus Berberis, 5 species of genus Lonicera, 6 species of genus Cotoneaster, Crataegus alma-atensis, C.transcaspica, Populus alba, P.bolleana, P.diversifolia, Rosa beggeriana); the Eastern Asian are 15 species (Ailanthus altissima, Berberis souliana, Crataegus chlorosarca, Viburnum burejaticum, Sophora japonica, Ligustrina pekinensis, Physocarpus amurensis, Spiraea japonica, 3 species of Acer, 2 species of Lonicera and $R o s a)-28 \%$.

Vegetation duration is $230-270$ days. The growth of plant shoots lasts longer, but the timing of shoots growth does not differ from the average dates for Mangyshlak. Despite the late end of vegetation, plants from these groups are mostly winter-resistant, slight freezing of annual shoots is noted in species from the genera Rosa, Symphoricarpos, Berberis, Lonicera and Cornus meyeri. Every year they give an outgrowth of 
shoots of 7-29 cm, only in the Central Asian species Populus alba, Polulus bolleana, P. diversifolia and the Eastern Asian species Ailanthus altissima, the annual increase is $43-48 \mathrm{~cm}$. Introduced plants from this group give full seeds. So, Ailanthus altissima is very well propagated by seeds of local reproduction, gives self-seeds, also it is successfully used in green building. Most plants from this group are mainly shrubs; belong to the 1-2 perspective groups. Plants from this group can freeze slightly, drought-resistant, flowering duration is 10-66 days, almost all species bear fruit. Bit, despite 25 years of age, the Eastern Asian species Acer truncatum, Acer pictum in Mangyshlak do not bloom and do not bear fruit.

Phenogroup CP has 17 species, among them the Northern American 10 species (Acer saccharum, Mahonia aguifolium, Cladrastis lutea, Quercus gambelii, Quercus rubra, Quercus macrocarpa, Juglans cinerea, J.nigra, Amorpha frangrans, Diospyros virginiana), the Central Asian (Armeniaca vulgaris, Amygdalus communis, Pyrus tadchikistanica) and the Eastern Asian (Tilia ledebouriana, Tilia mongolica, Pyrus lindleyi, Fraxinus rhyncophylla) - 9\%. The average vegetation duration is 173-225 days. Among taxa, the North American species Aser saccharum singly blooms, but does not bear fruit, and 3 species (Quercus gambelii, Quercus rubra, Quercus macrocarpa) have not reached the age of the generative phase, do not bloom, and accordingly do not bear fruit. The North American species Cladrastis lutea flower, but does not bear fruit. The Eastern Asian species Fraxinus rhyncophylla, despite its full age (more than 30 years in culture) does not bloom and does not bear fruit. Species of the genus Juglans and Tilia burn strongly in the summer and most leaves and young shoots lose turgor, and in other species only in the afternoon there is some loss of turgor leaves. All species of this group have low self-educational ability (annual increases in shoots are $5-13 \mathrm{~cm}$ ).

By parameters of perspectivity, the Northern American species are mainly assigned to $2^{\text {nd }}$ group. The absence of flowering and fruiting of Acer saccharumi and 3 species of Quercus, despite their high winter resistance, attributed them to the 3 perspective grop (less promising); and Juglans cinerea, J. nigra - to the $4^{\text {th }}$ perspective group (little promising). The Eastern Asian species were assigned to the 2nd perspective group, excepting Fraxinus rhyncophylla, which belongs to the 3rd perspective group. The Central Asian species (Armeniaca vulgaris, Amygdalus communis) are very promising, reproduce well with seeds, give self-settling, and are successfully used in landscaping.

The CC phenogroup has 28 species (the Northern American - 17 species: Ptelea serrata, Philadelphus hirsutus, Ph. lewisii, Fraxinus lanceolata, F.acuminata, Salix fragilis, Amorpha fruticosa, A. schafranifolia, Robinia pseudoacacia, Crataegus crus-galli, Crataegus kellermanii, C.lanuginosae, Gleditsia aguatica, G.triacanthos, Gymnocladus dioecus, Cercis canadensis, Calycanthus occidentalis; the Central Asian - 8 species: Morus nigra, Cr.turkestanica, Cydonia oblonga, Koelreuteria apiculata, K.bipinnata, Prunus spinosa, Nitraria schoberi, Rhamnus sintenisii; the Eastern Asian - 3 species: Pyrus bretschneideri, Fontanesia fortunei, Ulmus pumila) $-3 \%$.

Plants from this group begin and end vegetation in the average period with a vegetation duration of 182-223 days, with complete blanketing of shoots, frost is not observed. Plants of all species retain their inherent form of growth, have an average shoot-formed ability $(5-15 \mathrm{~cm})$; excepting the Northern American species - Gleditsia triacanthos $(30 \mathrm{~cm})$, Robinia pseudoacacia $(29 \mathrm{~cm})$, Fraxinus lanceolata $(20 \mathrm{~cm})$ and Koelreuteria apiculata $(35 \mathrm{~cm})$; the Eastern Asian species Ulmus pumila $(42 \mathrm{~cm})$, which have a high shootformed ability, annually give full seeds. Local reproduction plants are obtained from seeds, which are successfully used in landscaping. The drought resistance of the most promising species from the CC pheno group is 1 and 2 points, with the exception of some (Crataegus lanuginosae, Cercis canadensis, Salix fragilis -3 points). Most plants mainly belong to the $1^{\text {st }}$ and $2^{\text {nd }}$ group of plant prospects, except for 2 species of the genus Philadelphus and species Cercis canadensis (not drought resistant), Gymnocladus dioecus, Salix fragilis and Calycanthus occidentalis (only bloom, but do not bear fruit), therefore belong to $3^{\text {rd }}$. In the Eastern Asian species Ulmus pumila in recent years, in early July, leaves are damaged by pests (ilm leaf). This species, despite the very high drought resistance, is assigned to the 2 nd perspective group.

Phenogroup CП has 25 species (the Northern American - 17 species: Rhus toxecodendron, Rh. typhina, Rh.trilobata, Celtis occidentalis, Catalpa speciosa, Crataegus macracantha, Cr.phaenopyrum, Cr.uniflora, Cornus obligua, Maclura aurantiaca, M.pomifera, Forestiera neo-mexicana, Platanus occidentalis, Gleditsia texana, Cornus amomum, Padus serotina, S.menzieesii; the Central Asian: Fraxinus sogdiana, Fraxinus syriaca, Mespilus germanica, Paliurus spina-christi, Rhamnus arguta, Rhamnus dolicophylla; the Eastern Asian species: Gleditschia caspica, Zizyphus jujuba) - $13 \%$.

The duration of vegetation is 204-246 days, with an average vegetation onset, a late end, almost before frosts (December) and a later change in leaf color and leaf fall. Plants of all species of this group have low 
$(5-10 \mathrm{~cm})$ and medium $(12-25 \mathrm{~cm})$ shoot-forming ability, only 2 species of the genus Catalpa, species of Cotoneaster, Rhus typhina, the Central Asian species Fraxinus sogdiana and the Eastern Asian species Gleditschia caspica have high shoot-forming ability $(25-32 \mathrm{~cm}$. Basically, the tops of annual shoots freeze slightly in plants of this group, except Rhus typhina and Cornus obligua, in which $50 \%$ of the ends of annual, biennial and older shoots freeze in cold winters. Plants of this group are mainly drought-resistant, with the exception of species from the genus Catalpa, which in hot, dry summers the leaves burn up and lose turgor, but, with a decline in high temperatures, they recover. Plants from this pheno group mainly belong to $1^{\text {st }}$ and $2^{\text {nd }}$ perspective groups.

The highest indicators (106-112 points) scored species of the most promising group: taxa of the Northern American flora (Acer negundo, Gleditsia triacanthos, Robinia pseudoacacia, Fraxinus lanceolata and species of genus Lonicera, Rosa, Amorpha, Crataegus); the Central Asian flora' species (Acer semenovii, Armeniaca vulgaris, Amygdalus communis, Berberis iliensis, B.oblonga, Morus nigra, Nitraria schoberi, Koelreuteria apiculata, K.bipinnata, Fraxinus sogdiana, Populus diversifolia); species from the Eastern Asian flora (Acer ginnala, Ailanthus altissima, Malus baccata, Koelreuteria paniculata, Hemiptella davidii, Sophora japonica, Spiraea japonica, Rosa rugosa, Zizyphus jujube).

\section{Conclusion}

The dynamics of the development of introduced plants varies significantly depending on climatic factors. A comparative analysis of phenological observations made it possible to establish some differences, which are expressed in the change in the timing of the onset of individual phenophases and a significant reduction in their duration. So, for cold spring and humid, moderately hot summer growing periods, later (from the second decade of March) extended onset dates (until the third decade of November) and the duration of phenophases are characteristic. In warm spring, arid and hot summer years, phenophases are more compressed (from the $3^{\text {rd }}$ decade of February to the $1^{\text {st }}$ decade of November). The difference in the timing of the beginning of vegetation is 5-10 days, flowering and fruiting - up to 15-20 days. The intensive growth of shoots of woody plants begins from the 1st decade to the 3rd decade of April; the earliest start date of the phase was noted in March, before the onset of summer extremely high temperatures, the most recent - at the end of June, growth lasts until June-August. Flowering in different species begins from the 2nd decade of April to the 3rd decade of May, on average for 10-25 days. Extreme flowering dates are at the beginning of March and the end of June. The beginning of ripening of fruits is noted from July to the 1st decade of November with a difference of 45-50 days between species. The beginning of the leaf fall begins in midSeptember, the end of the leaf fall - from November 15 to 20 with a difference between species of 15-20 days.

Among 183 deciduous woody plants, which have undergone introduction tests, 52 species $(28.96 \%)$ belong to the first group (the highest) of perspective (among them the Northern American - 16 taxa, the Central Asian - 25 taxa, the Eastern Asian - 11 taxa); 95 species (54.1\%) - to the second group (high) of perspective (among them the North American - 28 taxa, the Central Asian - 29 taxa, the Eastern Asian 38 taxa); 34 species (16.9\%) are assigned to the 3 group (average) of prospects (among them the Northen American - 20 taxa, the Central Asian - 2 taxa, the East Asian - 12 taxa); 2 Northern American species $(6.6 \%)$ - to the fourth (low) group. According to the vegetation dates, there was an increase in plant prospects in Mangyshlak conditions for pheno groups from PP to PП, a decline in CP and an increase in CC; flowering and fruiting of most species indicates the success of their introduction and high prospects for further use.

For form an electronic DB developed by the Mangyshlak Experimental Botanical Garden, the computer program «DInCeR» introduces information on biology and ecology, registration number, year of involvement, donor-organization, type of reproductive material, number of copies, occupied area. The specified computer program on indicators «Stability,» «Decoration,» «Reproducibility» and «Application» using the regional scale on collectible tree species diagnoses the introductive value of plants [17].

\section{Acknowledgements}

The work was carried out with the support of the state grant of the Committee of Science of the Ministry of Education and Science of the Republic of Kazakhstan (AP05130997) «Study of the features of the adaptation reaction of plants to the limit factors of the habitat in the arid conditions of the Mangystau desert as the scientific and theoretical basis for their conservation and rational use ex situ». 


\title{
References
}

1 Иманбаева А.А. Древесные растения Мангышлакского экспериментального ботанического сада. 40 лет интродукции / А.А. Иманбаева, О.Н. Косарева, А.Т. Туякова. - Актау, 2012. - 244 с.

2 Иманбаева А.А. Особенности роста и развития инорайонных лиственных древесных растений в аридных условиях Мангышлака / А.А. Иманбаева // Плодоводство и ягодоводство России. - 2017. - Т. 51. - С. 146-154.

3 Методики фенологических наблюдений в ботанических садах СССР // Методики интродукционных исследований в Казахстане. - Алма-Ата: Наука, 1987. - С. 4-35.

4 Пятницкий С.С. Практикум по лесной селекции / С.С. Пятницкий. - М., 1961. — 271 с.

5 Лапин П.И. Оценка перспективности интродукции древесных растений по данным визуальных наблюдений / П.И. Ляпин, С.В. Сиднева // Опыт интродукции древесных растений. — М.: ГБС АН СССР, 1973. — С. 6-67.

6 Косаев М.Н. Оценка перспективности интродукции древесных растений / М.Н. Косаев // Методики интродукционных исследований в Казахстане. - Алма-Ата, 1987. - С. 37-45.

7 Байтуллин И.О. Теоретические основы и методические подходы к интродукции растений в регионы с экстремальными климатическими условиями / И.О. Байтулин // Изв. НАН РК. Сер. биол. и мед. — 2010. — № 2(278). — С. 18-25.

8 Рубаник В.Г. Интродукция североамериканских растений на юге-востоке Казахстана / В.Г. Рубаник, И.Н. Солонинова. - Алма-Ата: Наука, 1989. - 172 с.

9 Культиасов М.В. Эколого-исторический метод в интродукции растений / М.В. Культиясов // Бюлл. Гл. бот. сада. 1953. - Вып. 53. - С. 15-41.

10 Петрова И.П. Инродукция древесных растений Средней Азии в Москве / И.П. Петрова. — М.: Наука, 1978. — 154 с.

11 Вавилов Н.И. Пять континентов / Н.И. Вавилов. - М.: Мысль, 1987. — 348 с.

12 Жуковский П.М. Культурные растения и их сородичи. Систематика, география, цитогенетика, экология, происхождение, использование / П.М. Жуковский. - Л.: Колос, 1971. - 752 с.

13 Гончаров Н.П. Центры происхождения культурных растений / Н.П. Гончаров // Вестн. ВОГиС. — 2007. — Т. 11, № 3/4. - С. 561-574.

14 Лапин П.И. Сезонный ритм развития древесных растений и его значения для интродукции / П.И. Лапин // Бюл. Гл. бот. сада. - 1967. - Вып. 65. - С. 13-18.

15 Щербацевич В.Д. Фенологические группы североамериканских лиственных деревьев и кустарников / В.Д. Щербацевич // Опыт интродукции древесных растений. - М.: ГБС АН СССР, 1973. - C. 125-152.

16 Imanbayeva A.A. Diagnostics of introduction value of herbs of natural flora in the conditions of Mangystau / A.A. Imanbayeva, I.F. Belozerov, M.Yu. Ishmuratova // Bulletin of the Karaganda University. Series Biology. Medicine. Geography. - 2018. — № 4/92. - P. 54-58.

17 Imanbayeva A.A. Formation of the electronic database of the collection gene fund of the Mangyshlak experimental botanical garden / A.A. Imanbayeva, I.F. Belozerov // EurAsian Journal of BioSciences. — 2019. — Vol. 13, № 2. — P. $1405-1410$.

\author{
А.А. Иманбаева
}

\section{Маңғыстаудың аридті жағдайында ағаш тектес өсімдіктерін интродукциялаудың перспективасын бағалау}

\begin{abstract}
Ағаш өсімдіктерінің перспективалы және тұрақты таксондарын интродукциялық зерттеу және анықтау Қазақстанның жасыл құрылысы мен сәндік бағбандылығы үшін маңызды қолданбалы мәнге ие. Жергілікті флораның төтенше жағдайлары мен ағаш өсімдіктерінің тапшылығымен ерекшеленетін арид жағдайлары үшін тұрақты дақылдарды таңдау маңызды. Мақалада өсімдіктердің маусымдық өсу ырғағы мен дамуын зерттеу бойынша деректер берілген, олар вегетацияның басталу мерзімдерінің өзгеруінен (5-10 күн), гүлдену және жеміс беру (15-20 күн) мен олардың ұзақтығының қысқаруының өзгерісін көрсетті. Маңғышлақтың аридті жағдайында вегетация мерзімі бойынша ЕЕ-ден (вегетацияның ерте басталуы және ерте аяқталуы) ЕК-ке (вегетацияның ерте басталуы және кеш аяқталуы) дейін фенотоптар бойынша өсімдіктердің перспективалық сандарының өсуі, ОЕ-ден (вегетацияның орта басталуы және ерте аяқталуы) құлдырау мен ОО-дан (вегетацияның орта басталуы және орта аяқталуы) өсу байқалады. 183 интродуценттерінің ішінен 52-і таксонды перспективалықтың бірінші тобына (жоғары), 95-i - екінші топқа (жоғары), 34-i - үшінші топқа (орташа) және 2-i - төртінші топқа (төменге) жатады, бұл өсімдіктер интродукциясының сәттілігін және оларды одан әрі қолданудың перспективалылығын көрсетті. Коллекциядағы ағаш тектес өсімдіктер бойынша Маңғышлақ эксперименталдық ботаникалық бағы әзірлеген «DInCeR» компьютерлік бағдарламасында электрондық деректер базасы қалыптастырылуда.
\end{abstract}

Кілт сөздер: Маңғыстау, аридті жағдайлар, интродукция, ағаш өсімдіктері, фенология, өсуі мен дамуы, перспективасы. 


\title{
А.А. Иманбаева \\ Оценка перспективности интродукции древесных растений в аридных условиях Мангистау
}

\begin{abstract}
Интродукционное изучение и выявление перспективных и устойчивых таксонов древесных растений имеет важное прикладное значение для зеленого строительства и декоративного садоводства Казахстана. Важное место занимает выбор устойчивых культур для аридных условий, отличающихся экстремальными условиями и дефицитом древесных растений местной флоры. В статье представлены результаты по исследованию ритмов сезонного роста и развития растений. Установлены различия, которые выражаются в изменении сроков наступления начала вегетации (5-10 дней), цветения и плодоношения (15-20 дней) и сокращении их продолжительности. В аридных условиях Мангышлака по срокам вегетации отмечено нарастание баллов перспективности растений по феногруппам от РР (ранее начало и раннее окончание вегетации) до РП (раннее начало и позднее окончание вегетации), спад в СР (среднее начало и ранее окончание вегетации) и нарастание в СС (среднее начало и среднее окончание вегетации). Из 183 интродуцентов 52 таксона относятся к первой группе перспективности (высокая), 95 - ко второй группе (повышенная), $34-$ к третьей (средняя) и $2-$ к четвертой (низкая) из выделенных 6 феногрупп, что свидетельствует об успешности интродукции и перспективности их в дальнейшем применении. Формируется электронная база данных в компьютерной программе «DInCeR», разработанной Мангышлакским экспериментальным ботаническим садом, по коллекционным древесным растениям.
\end{abstract}

Ключевые слова: Мангистау, аридные условия, интродукция, древесные растения, фенология, рост и развитие, перспективность.

\section{References}

1 Imanbayeva, A.A., Kosareva, O.N., \& Tuyakova, A.T. (2012). Drevesnye rasteniia Manhyshlakskoho eksperimentalnoho botanicheskoho sada. 40 let introduktsii [The woody plants of Mangyshlak experimenta; botanical garden. 40 year of introduction experience]. Aktau [in Russian].

2 Imanbayeva, A.A. (2017). Osobennosti rosta i razvitiia inoraionnykh listvennykh drevesnykh rastenii v aridnykh usloviiakh Manhyshlaka [Features of the growth and development of foreign deciduous woody plants in the arid conditions of Mangyshlak]. Plodovodstvo i yahodovodstvo Rossii - Fruit growing and berry growing in Russia, 51, 146-154 [in Russian].

3 Metodiki fenolohicheskikh nabliudenii v botanicheskikh sadakh SSSR [Methodology of phonological observation in botanical gardens of USSR] (1987). Metodiki introduktsionnykh issledovanii v Kazakhstane - Methodlogy of introduction study in Kazakhstan. Alma-Ata: Nauka [in Russian].

4 Pyatnickij, S.S. (1961). Praktikum po lesnoi selektsii [Practicum on forest selection]. Moscow [in Russian].

5 Lapin, P.I., \& Sidneva, S.V. (1973). Otsenka perspektivnosti introduktsii drevesnykh rastenii po dannym vizualnykh nabliudenii [Assessment of the prospects of introduction of woody plants according to visual observations]. Opyt introduktsii drevesnykh rastenii Experience of introduction of woody plants. Moscow: Main Botanical Garden of AS USSR, 6-67 [in Russian].

6 Kosayev, M.N. (1987). Otsenka perspektivnosti introduktsii drevesnykh rastenii [Assessment of perspectivity of introduction of woody plants]. Metodiki introduktsionnykh issledovanii v Kazakhstane - Methodlogy of introduction study in Kazakhstan. AlmaAta: Nauka [in Russian].

7 Baitulin, I.O. (2010). Teoreticheskie osnovy i metodicheskie podhody $\mathrm{k}$ introduktsii rastenii $\mathrm{v}$ rehiony s ekstremalnymi klimaticheskimi usloviiami [Theoretical foundations and methodological approaches to plant introduction to regions with extreme climatic conditions]. Izvestiia NAN RK. Seriia biolohicheskaia i meditsinskaia - Bulletin of NAS RK. Series biology and medicine, 2(278), 18-25 [in Russian].

8 Rubanik, V.G., \& Soloninova, I.N. (1989). Introduktsiia severoamerikanskikh rastenii na yuho-vostoke Kazakhstana [Introduction of the Northern-American plants in the South-East of Kazakhstan]. Alma-Ata: Nauka [in Russian].

9 Kultiasov, M.V. (1953). Ekoloho-istoricheskii metod v introduktsii rastenii [Ecological-historical method on plant introduction]. Biulleten Hlavnoho botanicheskoho sada - Bulletin of Main Botanical Garden, 53, 15-41 [in Russian].

10 Petrova, I.P. (1978). Inroduktsiia drevesnykh rastenii Srednei Azii v Moskve [Introduction of Central Asian woody plants in the Moscow]. Moscow: Nauka [in Russian].

11 Vavilov, N.I. (1987). Piat kontinentov [Five continets]. Moscow: Mysl [in Russian].

12 Zhukovskii, P.M. (1971). Kulturnye rasteniia $i$ ikh sorodichi. Sistematika, heohrafiia, tsitohenetika, ekolohiia, proiskhozhdenie, ispolzovanie [Cultuvated plants and their relatives. Systematics, geography, cytogenetics, ecology, origin, using]. Leningrad: Kolos [in Russian].

13 Goncharov, N.P. (2007). Tsentry proiskhozhdeniia kulturnykh rastenii [The centers of origin of cultivated plants]. Vestnik VOGiS - Bulletin of VOGiS, 11(3/4), 561-574 [in Russian].

14 Lapin, P.I. (1967). Sezonnyi ritm razvitiia drevesnykh rastenii i eho znacheniia dlia introduktsii [Seasonal rythms of development of woody plants and their meaning for introduction]. Biulleten Hlavnoho botanicheskoho sada - Bulletin of Main Botanical Garden, 65, 13-18 [in Russian]. 
15 Shcherbatsevich, V.D. (1973). Fenolohicheskie hruppy severoamerikanskikh listvennykh derevev i kustarnikov [Phenological groups of North American deciduous trees and shrubs]. Opyt introduktsii drevesnykh rastenii - Experiences of introduction of woody plants. Moscow: MBG AS USSR [in Russian].

16 Imanbayeva, A.A., Belozerov, I.F., \& Ishmuratova, M.Yu. (2018). Diagnostics of introduction value of herbs of natural flora in the conditions of Mangystau. Bulletin of the Karaganda University. Series Biology. Medicine. Geography, 4/92, 54-58.

17 Imanbayeva, A.A., \& Belozerov, I.F. (2019). Formation of the electronic database of the collection gene fund of the Mangyshlak experimental botanical garden. EurAsian Journal of BioSciences, 13(2), 1405-1410. 